\title{
Forming Good Habits: A case for the homeless in the City of Tshwane ${ }^{1}$
}

\section{E Baron ${ }^{2}$}

\begin{abstract}
This article aims to address the issue of habit formation in the context of homeless people in the City of Tshwane. Subsequent to the conversation and Bible study with the group of homeless people, the author introduces the emerging themes that emanated from the encounter. The article demonstrates the formation of good habits and the struggle to get rid of bad habits.
\end{abstract}

Keywords: Habit formation, Habituation, Tshwane, homelessness, Urban Mission.

\section{Introduction}

The phenomenon of homelessness in South Africa is an undeniable fact. Many people are sleeping under bridges and on pavements, creating their own shelters with whatever they can get to have a "good" night's rest. Many homeless individuals have a regular spot where they sleep at night, while others tend to struggle to get another spot for the next night. Besides shelter, food and other basic physiological needs, homeless people also experience the challenge of forming good habits. Living and sleeping under bridges and on pavements creates an environment in which habits are adopted and practised. This, as I will illustrate in this contribution, is also the case in the engagement with homeless people in the City of Tshwane. During the Bible studies and interaction with this group of homeless people, it became evident that they have developed some bad habits, which they are struggling to get rid of. They struggle to transform particular ways of doing things, in order to behave and act in the best interests of themselves and others. Striving towards forming new good habits is not easy but, as observed through the group discussions, this remains a struggle. As part of analysing the context, the homeless were asked three questions. Their responses to these questions attest to the bad habits among them and their struggle to get rid of them. In the light of their own feedback, they expressed the ways in which they could change these bad habits.

1 This article was published as a chapter in the peer-reviewed book Pavement Encounters for Justice: Doing Transformative Missiology with homeless people in the City of Tshwane (Mashau \& Kritzinger 2014), that was a result of the Meal of Peace Project of the Dept. of Christian Spirituality, Church History and Missiology at Unisa. The editors and the authors (as copyright owners), have given permission that this version may be published in Missionalia, as an accredited South African journal.

2 Rev Eugene Baron is a lecturer in the Dept of Christian Spirituality, Church History and Missiology, at the University of South Africa. He can be contacted at barone@unisa.ac.za 
This article aims to address the forming of new habits in the context of the homeless people in the City of Tshwane, by starting with a brief introduction on the discourse around the formation of good habits. Secondly, a brief discussion on the methodological approach of Gerald West will be described that will serve as an analytical tool in this article, to address the issue of bad habits, and to develop a remedy from the synthesis that arises from the transformative encounter between trained readers and untrained readers. ${ }^{3}$ Thirdly, the texts (i.e. the focus text and the other secondary texts) that were used during the Bible study will be discussed from a trained reader's theological reading of the text. Then, fourthly, the texts are discussed from the perspective of the homeless, and how they made sense of the particular texts that were discussed. Finally, when the interpretation and comments on the text are carried out from the perspective of the trained and untrained readers, the article focuses on the themes that emerged from the encounter, and finally draws some conclusions.

\section{Background}

At the beginning of the new democracy in South Africa, there were many celebratory aspects in our society - for instance, the adoption of our new constitution, which promised to protect the basic rights of all the people in this country. The reconciliation process which was steered by the Truth and Reconciliation Commission of South Africa, under the leadership of Archbishop Desmond Tutu and its vice-chairperson Alex Boraine, was also one of the celebratory moments and processes which unfolded on South African soil and of which, as a nation, South Africans could be proud.

Despite these and other celebratory aspects that pointed to the bright side of the "new (democratic) South Africa", there were also those instances like corruption that were hovering over our beloved country (Boraine 2014:91). Those bad habits, which also include the involvement in corrupt activities that are being perpetuated in our societies and communities, are threatening the moral fibre of South Africa. Former president Nelson Mandela alluded to this "dark side" during his term of office, referring especially to issues like corruption. His response to this pervasive immoral conduct is well articulated in his State of the Nation address of 1999:

3 West (1993:8) makes the distinction between trained readers, whom he regards as those who "have had some Biblical studies training", and the ordinary readers of the Bible, who are those who "have had no formal Biblical studies training." In this article the author uses the word "trained" to refer to a scholarly perspective on habit formation, and "untrained" (or "ordinary") reader to refer to the homeless people who were part of the discussions. 
Our nation needs, as a matter of urgency, an 'RDP of the Soul'. When we succeed in changing our own way of doing things, when we make progress in transforming society at all levels, we shall not only be improving our own quality of life. We shall also be laying the basis for a future of hope for our children and grandchildren (Mandela 1999).

The changing of "how we do things," as referred to by the former statesman, would mean in an Aristotelian sense a change of character, which Nelson Mandela refers to as the "RDP of the soul." We should change our being (character) to be good. When discussing the issue of good habits, two related areas of discussion are considered important before engaging with the feedback of the homeless people in the City of Tshwane. The first is to ask what is a "good" person, and secondly, how we become good people. This quest in search of what it means to be good is notably documented in the classical writings of Plato and Aristotle (Conradie 2006:57). Aristotle made a significant contribution to the idea of being a good person, and he focused on four cardinal virtues: prudence, justice, temperance, and courage. Thomas Aquinas, a theologian and philosopher in the tradition of scholasticism, followed this Aristotelian tradition (of virtue ethics) which subscribed to the idea that it is not only about making good or "the right" choices, but that one should be a person of virtue (character). Aquinas focused in his treatise on three theological virtues: faith, hope and love (Conradie 2006:57-61). It is important to note that there are other virtues also that contribute towards being a "good" person.

These virtues, which constitute a good person in the way that Aristotle and Aquinas posit, are cultivated from a variety of sources. One of those sources is the community in which a person is born and raised. This notion is advocated by scholars such as Macintyre, Bansikiza and Hauerwas. Alasdair Macintyre $(1981 ; 1984)$ emphasised in his book After virtue the value and role that communities (the polis) play in the formation of people's virtues, while the emphasis of Bansikiza (which is also focused on the role of communities) makes special reference to African culture (Bansikiza 2001:11). Stanley Hauerwas, an American theologian and ethicist, places emphasis on Christian communities as the source of morality. Davis (1993:3) reflects on Hauerwas' view and states that the individual living the moral life outlined in the metaphors and stories of the Christian narrative tradition will challenge the social conditioning of his or her time, becoming transformed and striving to bring the love and peace that was portrayed through the life of Jesus to the world. These scholars believe that it is through one's life in the community that an individual learns how to behave and to act. 
After a brief discussion on what constitutes a good person, at least according to two Ancient Greek Philosophers, Plato and Aristotle, and the role of a faith community in becoming "good," it is now appropriate to discuss how a person can become "good," which is indeed of paramount importance, especially for this article which focuses on how good habits can be formed. Johannes van der Ven (1998), who is an influential Dutch theologian, wrote in his book, Formation of the Moral Self, of the seven modes which can serve as impetus in the life of an individual in his or her pursuit of becoming a good person. The modes he refers to are discipline, socialisation, transmission, development, clarification, emotional formation and education for character. The mode of discipline is quite important, as it relates to the idea of forming good habits. Aristotle's notion of attaining the four cardinal virtues, which were referred to earlier, is in line with this mode of discipline. According to Aristotle, the cardinal virtues can be developed through knowledge and training (Conradie 2006:57).

The training referred to by Aristotle is the same as saying that one should be disciplined in order to become a good person. Van der Ven argues that discipline is one of the informal ways of forming good character, and takes place as a result of the influences of parents and community life (see also Kretzschmar 2009:104). Furthermore, Van der Ven (1998) shows that discipline is an act of habituation - which means to form appropriate habits, which will help a child (and which occurs throughout a person's life) to perform the desired actions. According to the theory of Van der Ven, the mode of discipline will strongly lean towards the act of a person taking responsibility for his moral self and form appropriate habits to become a good person. The participation of one's self in the process of changing one's character is also articulated in the treatise of Wogaman (1979: Ch.2; cf. Koopman 2007:112), when he refers to the formation of one's character as an anthropological activity. He refers to the role that the Holy Spirit plays in the formation process, but adds that it is not only the work of the Holy Spirit but also of the individual, if the individual desires change.

The pursuit of becoming a good person through the practice of adopting good habits has also been explained by some psychologists, particularly through the role of the brain, and puts the focus on the biological, cognitive processes, while other psychologists focus on the role of outside influences and stimuli. The biological process in habit formation resonates with the notion that there is a particular area of the brain that is responsible for the forming of habits. The basal ganglia (Kosslyn \& Rosenberg 2011: 60), which is the brain structure that is identified as the one which plays a role in habit-forming, is explained as follows: "[w] hen you learn to put your foot on a car's brake automatically at a red light....", it is then that " $\ldots$ the basal ganglia is busy connecting the neural signals produced when you see the stimulus (light) with the parts of the brain that produce your response (moving your foot)" (Kosslyn \& Rosenberg 2011:60). 
According to the psychologists who support the aforementioned theory, the action of habituation ${ }^{4}$ and dishabituation ${ }^{5}$ appears as an automatic process and, as Sternberg \& Sternberg (2012:177) remark, occurs already hours after birth. Various tests were performed that show how infants habituate to certain aspects in their lives in terms of attachment (Berk 2013:430), categorisation (Berk 2013:234-235) and object perception (:230-231). These research studies were performed and pointed out how children habituate (form habits in relation to) these aspects. This theory therefore accentuates the idea that habituation (the process of forming habits) is primarily a biological process.

The forming of good habits is also articulated as part of research that was done by some behavioural scientists who focused on how people learn through being regularly exposed to a specific stimulus (Meyer et al. 2008:262-271). One of these scientists is Ivan Petrovich Pavlov (1849-1936) who was known for his research that was carried out by testing a dog, and thereby attested as to how people learn through being exposed to a specific stimulus (Meyer et al. 2008:270). This theory of learning new behaviour is called "classical conditioning." Pavlov noticed that the dogs used in his experiment salivated before they were provided with food, and made the conclusion that "any neutral stimulus such as a bell, which initially did not elicit the salivatory reflex, was sufficient to evoke a flow of saliva if, on a few occasions, it was presented at the same time as the food. Pavlov called this the conditioned reflex, because salivation is an involuntary reflex to food" (Meyer et al. 2008:252-253).

The constant exposure to a specific stimulus causes an individual to react habitually in the fashion to which the person was conditioned. A good example is the persuasive appeals used in the marketing and advertising industry. The advertisers use some celebrities and place them next to the item, product or service that they want to market, and want their audiences to purchase. If the advert of the particular product or service is repeated often enough on television or billboards, the product will subconsciously be linked to the celebrity, and will be favourably observed (provided the celebrity is a credible figure according to the market audience). This is one of the examples of how the theory of Pavlov (also known as classical conditioning) explains the learning of new habits. It also explains why certain people become "automatically" positive - and sometimes even addicted - to a certain product or any other performed action (Meyer et al. 2013:269).

4 According to Berk (2013:142), habituation refers to a gradual reduction in the strength of a response due to repetitive stimulation.

5 Dishabituation refers to the process of enhancing a particular habit that was weakened through the continuous performing of that habit and stimulating it by making use of a new stimulus. 
Another way of conditioning, which is referred to as operant conditioning (where behaviour is controlled by stimuli that come after the act) is through acts of punishment or reward; by censuring or praising people for bad and good behaviour (Meyer et al. 2013:270-277). These two actions (i.e. punishment and reward) act as methods to reinforce good and bad behaviour and, according to behaviourists, play a role in a person's decision to abstain, proceed or concede in his or her way of doing things (which was the concern raised in the State of the Nation address of 1999 by former president Nelson Mandela) (Meyer et al. 2013:270-277). Taking all these ways of habituation into account, it is fair to say that habituation serves as a way of changing or forming a person's character (Meyer \& Moore, 272-273), irrespective of the particular psychological theory one regards as the best explanation for habit-forming behaviour.

\section{Research Methodology}

Besides the brief background sketch on the discourse around the forming of new habits, the author also engaged in discussions and conversations with the group of homeless people, to prevent this article from being a reflection on habituation presented solely from a scholarly vantage point. The reflections of the homeless people in the City of Tshwane were studied by using the contextual Bible study approach of Gerald West (1993), as explained in previous articles. According to West (1993:11-12), to read the Bible contextually means at least to make the commitment: (1) "to read the Bible from the perspective of the South African context, particularly the perspective of the poor and the oppressed;" (2) "to read the Bible in the community with others, particularly with those from contexts different from our own;" (3) "to read the Bible critically;" (4) "a commitment to individual and social transformation through contextual Bible study." The author used this approach as a guideline when interpreting the focus text in Ephesians $4: 17-25$. The secondary texts that were also reflected upon during the discussions with the group were Mark 9:42-48, 1 Tim 4:7 and Rom 12:1.

The following sections will provide a theological, trained reader's perspective of the focus text. In this section the author discusses the commentators' remarks on the focus text, and what they regard as the original meaning of the text. Then the author presents the views of the homeless group ("ordinary" or "untrained" readers) that were collected from them during the Bible studies that created a space for them to share their views, without pressure or prejudice. How the homeless people understood the texts was important and was therefore also documented by the author. To make sense of habit formation in the context of the homeless, the author discussed the major themes that emerged from the two perspectives and vantage points - both scholarly and "ordinary." 


\section{Theological Reflection}

Before engaging with the original purpose and reason for the writing of the focus text, the authorship and audience to whom the letter is addressed will be briefly discussed. Besides some uncertainty around the authorship of the book of Ephesians (see Harvey 2012:75; Macdonald 2000:15; Vanhoozer 2009:124-125), most commentators concede that Paul is the author and that this book was most probably written by Paul while he was in prison (most probably in Rome). With regards to the audience to whom the letter was addressed, MacDonald $(2000: 17)$ believed there were at least two recipients. He believed that the "we" used by the author throughout the focus text referred to the Jewish Christians living in the city of Ephesus, and when it used "you," it referred to the Gentile Christians also living in Ephesus. Morris (1994:135) regards these Gentiles (who were also part of the Christian community in the city of Ephesus) as the recipients of the letter. In general, the Jewish community, whether Christian of non-Christian, referred to Gentiles as those who do not acknowledge or worship the one true God. They are also referred to in other New Testament epistles as "pagans" (Morris 1994:135; The New Interpreter's Bible 2000:428). But Paul addressed these Gentiles who had become Christians and reminded them of the other Gentiles, and of their sinful lifestyles and behaviour. He reminded these Gentile Christians of how they had lived in the past, but also how they needed to change their behaviour - having become Christians.

The Gentile Christians who were the recipients of the letter were admonished by Paul throughout the focus text. This admonition is better understood when the focus text is placed within the broader framework of the whole letter. It is within the broader framework of this letter that Harvey (2012:75) argues that the following themes are put forward. The Christian Gentiles should have an "Understanding of the believer's wealth, walk and warfare in Christ." According to Harvey (2012:75), this particular section (Ephesians 4:17-25) forms part of the "walk in Christ" section. This particular section was also tagged by Hendrickson (1967:208), but he identified the theme as "renewal." These notions of Harvey and Hendrickson put emphasis on the conduct of Christians, how they should live and conduct their ways, but also how they should change their ways, if their present behaviour is not acceptable to God.

Furthermore, in the quest towards a better understanding of the purpose of this letter, and of Paul's admonition in the focus text, notice should be taken of the relevance of the context. In the first century, the city of Ephesus was a thriving commercial centre, with a predominantly Gentile population and just enough Jews to support a synagogue. Harvey (2012:129) pointed 
out that much of the city's commerce "related to the temple (of Artemis), and two major spring festivals celebrated the Artemis cult." Moreover, he comments that "Magic played a major role in the worship of Artemis and made the city a centre for occult practices."

The focus of Ephesians 4:17-25, according to Morris (1994:133), should be read in the light of all God has done for His people (sending His Son). Paul uses the word "therefore" at the start of the focus text (v.17) to urge them as Christians in Ephesus not to go along with the evils that manifest themselves through the lives of the Gentiles living in the city of Ephesus. Paul urges them to live the new humanity brought about through the cross of Christ (Eph 2:11-22).

The reason why Paul focused their attention on how they have to live in the new humanity in Christ could be because he "recognized the pull exerted on the new Christians by their former habits" (Morris 1994:134), especially when we take their own context and the Gentile city in which they were residing into consideration. Paul brings his point across by the insertion that they "should no longer walk as the Gentiles walk." According to Morris (1994:134) this refers to the way in which they habitually walked. They were used to (conditioned by) the lifestyle of their fellow Gentiles before accepting Jesus Christ, which now constrains them to adopt a different lifestyle. But if they continue to live like the Gentiles, Morris warns that they will walk farther and farther away from God, proceeding in the "ways of the Gentiles." When Paul focuses on the type of actions that are typical of a Gentile lifestyle, he emphasises their "lack of sensitivity," which means insensitivity to the pain of other people, but also to the will of God, acting as the supreme arbiters of their own actions (leading to licentiousness) (Morris 1994:137).

Throughout the focus text, the difficulty of "putting off" the "former self," which refers to a Gentile lifestyle, is reflected by Paul as a difficult, strenuous exercise, which is often painful, since the old life is "not easy to shed" (Hendrikson 1967:214). To "put away the old man" means that being a Christian is entering a whole new way of life" (Morris 1994:140):

It does not mean to carry on with the old way with perhaps a few of our worst habits dusted off... but to become a Christian means more than eliminating a few minor bad habits (Paul urges that we be renewed in the spirit of our minds); it means a complete overhaul, the re-making of all of life.

The "putting off" referred to by Paul in this text is to be done once and for all, as it is in the original text in the aorist tense and the infinitive, whereas "renewal" or "putting on" is in the infinitive and present tense, which means this should be a perpetual and continuous action that should take place (Barth 1974:505). This "putting off," according to Paul, is part of an inward change, especially when Paul speaks of the "spirit" and the "mind" (Morris 
1994:141). Roberts (1991:141) seems to have the same line of thought as Morris, when he refers to the spirit or the mind as the innermost being (as the text refers to), as "the deepest part of one's being, the place where ideas have their origin." The inner part, the spirit of the mind, is exactly the place where change and the "putting off" of the old habits should take place.

After the "putting off," Paul starts to focus his attention on the "putting on." Hendrikson (1967:215) points out that the positive (to put on) should be given the same weight as the negative (to put off), and he also stresses the success of the above action, as Morris does. The success of the "putting off" lies in being "renewed in the spirit of one's mind." He explains that the renewing of the "spirit of one's mind" happens as an act of God's Spirit which powerfully influences the human spirit, also the mental attitude, state of mind or disposition (Hendrikson 1967:215).

In reflection on this passage of Scripture, the New Interpreter's Bible (2000:431) remarks: "We all know that whenever we decide to make a major life change, perhaps to adopt a new habit of diet and exercise or emotional and spiritual health, the transition takes time and discipline." Taking this remark into account, we can make the following conclusion, after the overall exegesis of the text - that the decision, which is the inward change, should take place once and for all, whereas the process of forming new ways of living which is acceptable to Christ takes time and discipline.

\section{The Encounter}

Before engaging with the homeless in their interpretation of the focus text (Ephesians 4:17-25), a general discussion around the issue of habituation preceded the discussion of the focus text, in order to ascertain a sense of the broader context of the homeless people. In their response, the group admitted that they had bad habits which were not good for them and mentioned, amongst others, some bad habits like biting their nails and getting angry easily, while others also reported their smoking habits which could put them at risk for various health-related issues. They also mentioned how they were incapable of handling their own finances, although it did not involve much money. Sometimes they also say some bad things to others, without minding their words.

They also went further and described the impact or the influence such habits had on their daily lives. They mentioned how some of those bad habits embarrass them. One participant also expressed himself in the following way, when referring to a personal incident that happened: "I once said something bad to my husband and it ended up with a fatality: my husband killed our child, and I feel ashamed in my heart." They reported also how their bad habits created a guilty conscience within them, especially when their bad habits resulted in poor physical, mental and spiritual health, 
and how it caused them to feel guilty. Furthermore, it caused them to live a sinful life, to desire other people's property, and also caused them to lose important material things in life.

Their struggle to get rid of these bad habits was evident in their responses to the question as to how they think they could change their bad habits. They mentioned that they constantly tried various ways, which included ignoring and trying to avoid perpetuating these bad habits. They often tried to be nice to people and to pray about their bad habits, in their quest to get rid of those bad habits, but it did not necessarily free them from the grip of these habits. They also engaged in efforts to get help to control their anger, and in some cases they also ventured and got involved in good relationships, in the quest to abandon their bad habits. Further actions included focusing on the things they enjoyed in life, and attending some counselling sessions.

A final focus of the general discussion around habituation was based on the feedback from the group that their remedial actions did not always pay off. Their belief was that in order for them to get rid of those bad habits, they should "take one step at a time." One of the homeless even remarked that the reason they often failed to get rid of their habits was also because they live "with wrong company," while others responded that it was partly due to their failure to "take control of [their] life," and "relying on [their own] strength more than involving God."

The second part of the discussion with the group was trying to understand how they understood the focus text (Ephesians 4:17-25). Their perception and interpretation of the text does not differ greatly from the scholarly interpretation. The focus text for them is about change. It is about changing a bad action to a good action. It is also to get rid of the old self, to stop lying and to start preaching the Word of God. Besides the focus text, there were secondary texts that were used during the encounter. Their responses to the text in Mark 9:42-48 were that the text is about "doing the right things." Others said: "It is also to admire but not to sin" and that the text is "calling us to change our bad habits." The group also argued that this text signals a warning not to cause the young and the innocent to turn away from the Lord. According to the group, the next passage (1 Tim 4:7) was about the idea of being trained in what is good. The last text that was presented to them during the discussion was Rom 12:1, and in their feedback they made it clear that this text is mainly about people not being "like the world, but transforming their minds." 


\section{Synthesis}

During the discussions and conversations with the group, contextual meanings emerged of what the formation of good habits entails. The meanings that emerged after taking into account the voices of the homeless and the theological interpretation of the text brought forth a few emerging themes that need some discussion.

The first theme that emerged was the continuousness of habit-forming behaviour. Habituation, as emerging through both perspectives (both scholarly and ordinary readers), showed that it is not a "once-off" deal, but needs to be part of one's everyday life. It should be seen as a process. The forming of good habits will always be part of any individual's life, until they depart from this earth. This is confirmed through the scholarly and theological interpretation of the focus text, in particular where Paul used the image of "putting off" and "putting on." These two actions should be part of the life-long process of becoming a good person with good habits. The homeless people also reflected on how they had attained their bad habits and on how, in order to acquire new habits, they should abandon the old ones. They indicated that no one will ever reach the stage where the process of getting rid of the old habits and attaining good habits comes to an end; they committed themselves, instead, to the continuous struggle of this process in their everyday lives.

The "putting off" and "putting on" in the voice of Paul in the focus text is not just articulating the process, as stated in the former paragraph, but it also points to the effort required by each individual in their endeavour to acquire new habits. The forming of good habits has to do with a person's own actions, and efforts in the process of striving to become (imperative) what God has already made that person (indicative) in and through the cross and resurrection of Christ. ${ }^{6}$ The group of homeless people spoke at length during the discussions about their own involvement in the process and of their struggle to get rid of the old habits and to form new, good ones. Their arguments are in line with the argument of Paul, that the person's effort should be to "put off" and "put on." The behavioural perspective also underlines the involvement of outside influences and the conditioning of a person's behaviour, which underline the notion of personal responsibility.

Habituation is a feasible process. It emerged, through the encounter with the homeless, that it is indeed within an individual's reach to learn and acquire new habits. The acquiring of new habits therefore is perceived also by the homeless as an attainable action. The homeless conveyed their

6 In this respect it is important to underline the point made earlier that Eph 4 should not be read in isolation from Eph 1-3, in which the indicative of God's salvation through Christ is explained and celebrated. Eph 2:1-10 is particularly pertinent in this regard to prevent one's reading of Eph 4:17-25 from becoming a moralistic exercise in self-improvement. 
periodic failure to get rid of the old habits, but it did not mean that they were not capable of forming good habits. However, they only emphasised the difficulty of doing so. What makes this discussion even more complex is when we take into account the psychological explanation for habituation, one of the viewpoints to the biological processes that are involved in the forming of new habits, and the role of the brain in habituation. When new habits are formed, the brain creates new neural pathways, and erodes the old ones. This implicitly means that it is, at least from the scholarly perspective, not easy to get rid of the old. But this also does not mean that new neural pathways cannot be created, when we also take into account the experiences of the homeless and their remarks.

\section{Conclusion}

This contribution engaged with a group of homeless people in the City of Tshwane, in order to get their contextual understanding of the issue of habituation. The focus text in Ephesians 4:17-25 was interpreted from a scholarly perspective, but also from a "grass roots" or "pavement" perspective, listening to the experiences, sentiments and understanding of a group of homeless people. They identified the "bad habits" that found expression in their lives on the pavements of the City of Tshwane. They are engaging in various ways to "take off" those habits in the Pauline sense and "putting on" new ones, with the hope that they will manage to live a life that is good - and valued by others.

\section{Bibliography}

Bansikiza, C. 2001. Restoring Moral Formation in Africa. Kenya: AMECEA GABA Publications.

Baron, R.A., \& Branscombe, N.R. 2012. Social Psychology. 13th Edition. Boston: Pearson

Barth, M. 1974. The Anchor Yale Bible. Ephesians. Introduction, Translation and Commentary on Chapters 4-6 by Markus Barth. New Haven, London: Yale University Press.

Berk, L.E. 2013. Child Development. Ninth Edition. Boston: Pearson

Conradie, E.M. 2006. Morality as a way of life. A first introduction to ethical theory. Stellenbosch: Sun Press.

Harvey, J.D. 2012. Handbooks for New Testament Exegesis. Interpreting the Pauline Letters. An Exegetical Handbook. Grand Rapids, MI: Kegel Publications. 
Hendrikson, W. 1967. New Testament Commentary. Exposition of Ephesians. Grand Rapids, Michigan: Baker Book House.

Koopman, N.N. 2007. Towards a Human Rights Culture in South Africa. The role of moral formation. NED GEREF Teologiese Tydskrif, 48 (1\&2): 107-118.

Kosslyn, S.M, Rosenberg, R.S. 2011. Introducing Psychology. Brain, Person, and Group. Boston: Pearson.

Kretzschmar, L, Bentley, W, Van Niekerk, A (eds). 2009. What is a good life? An Introduction to Christian Ethics in the 21st Century Africa. Parow: AcadSA Publishing.

MacDonald, M.Y. 2000. Sacra Pagina Series. Volume 17. Colossians and Ephesians. Collegeville, Minnesota: Liturgical Press.

Mandela, N. 2006. State of the Nation Address. Pretoria: Government Gazette.

Meyer, W.F. Moore, C., Viljoen, HG. 2008. Personology. From Individual to ecosystem. Fourth Edition. South Africa, Sandton: Heinemann Publishers.

Morris, L. 1994. Expository Reflections on the Letter to the Ephesians. Grand Rapids, Michigan: Baker Books.

Sternberg, R.J., \& Sternberg, K. 2012. Cognition. 6th ed. Canada: Wadsworth.

The New Interpreter's Bible. 2000. Volume XI. Nashville: Abingdon Press.

Van der Ven, J.A. 1998. Formation of the moral self. Grand Rapids, Cambridge: Eerdmans.

Vanhoozer, K,J. (eds) 2008. Theological Interpretation of the New Testament. Great Brittian: SPCK

West, G.O. 1993. Contextual Bible Study. Pietermaritzburg: Cluster Publications.

Wikipedia. Habit. Accessed online from http://en.wikipedia.org/wiki/Habit on $2014 / 10 / 30$

Wogaman, J.P. 1979. Christian Moral Judgement. London: SCM Press. 